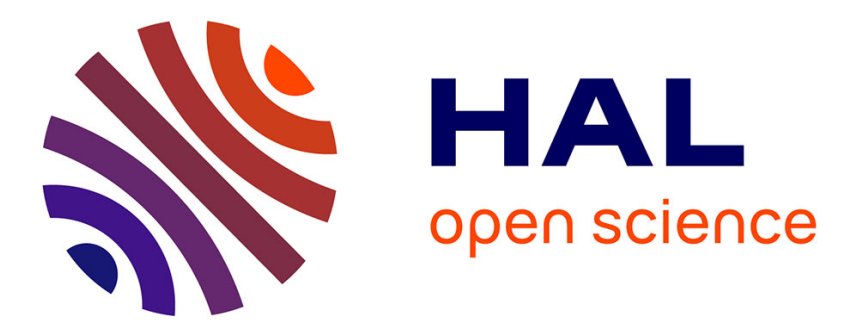

\title{
Experimental investigation of the thixoforging of tubes of low-carbon steel
}

Eric Becker, Régis Bigot, Sophie Rivoirard, Pierre Faverolle

\section{To cite this version:}

Eric Becker, Régis Bigot, Sophie Rivoirard, Pierre Faverolle. Experimental investigation of the thixoforging of tubes of low-carbon steel. Journal of Materials Processing Technology, 2018, 252, pp.485497. 10.1016/j.jmatprotec.2017.10.003 . hal-02308261

\section{HAL Id: hal-02308261 \\ https://hal.science/hal-02308261}

Submitted on 8 Oct 2019

HAL is a multi-disciplinary open access archive for the deposit and dissemination of scientific research documents, whether they are published or not. The documents may come from teaching and research institutions in France or abroad, or from public or private research centers.
L'archive ouverte pluridisciplinaire HAL, est destinée au dépôt et à la diffusion de documents scientifiques de niveau recherche, publiés ou non, émanant des établissements d'enseignement et de recherche français ou étrangers, des laboratoires publics ou privés. 


\title{
EXPERIMENTAL INVESTIGATION OF THE THIXOFORGING OF TUBES OF LOW-CARBON STEEL
}

\author{
Eric BECKER ${ }^{1, a^{*}}$, Régis BIGOT ${ }^{1, b}$, Sophie RIVOIRARD ${ }^{2, c}$, Pierre \\ FAVEROLLE ${ }^{3, d}$ \\ ${ }^{1}$ Laboratoire de Conception, Fabrication et Commande - Arts et Métiers ParisTech - 4, rue \\ Augustin Fresnel - F57078 Metz FRANCE \\ ${ }^{2}$ NEEL Institut, CNRS/UGA UPR2940 - 25 rue des Martyrs BP 166 - F38042 Grenoble cedex 9 \\ ${ }^{3}$ VALEO PES - 2 rue André Boulle - F94046 Créteil cedex- FRANCE \\ aeric.becker@ensam.eu, ${ }^{b}$ regis.bigot@ensam.eu, csophie.rivoirard@neel.cnrs.fr, \\ dpierre.faverolle@valeo.com
}

Keywords: Thixoforging, low-carbon steel grade, backward and forward extrusion.

\begin{abstract}
This article presents the outcomes of using thixo-extrusion (backward and forward) to produce tubes in low-carbon steel, grade SAE1006 (C05). According to the literature data, the semisolid state of this steel, required for thixoforging, is very difficult to obtain and has never been studied for this type of shaping. The experimental tests involve using an inductive heating and a flashless forging process. This work shows the route and possibility to obtain a usable semisolid by inductive heating for thixoforging of this steel grade. It shows by simulation the validation steps before the shaping and the forming constraints. A geometrical analysis of the parts revealed the good dimensional performance of thixoforging processes with high repeatability and a good microstructure. Such thixoforged tubes extend the dimensional limits of the tube wall thickness, as compared to the case of conventional forging in one step and in the framework of a typical industrial installation. These results could be integrated into a knowledge management system of thixoforging to identify new possibility of components.
\end{abstract}

\section{Introduction and context}

Püttgen et al. (2007) said that metal alloys forming at the semisolid state appears to present economic and product earning opportunities by combining the advantages of forging and casting. Cézard (2008) made a presentation of the advantages (e.g., reducing the shaping cycle, forming energy, reduction required machining, and dimensional and geometric tolerances and enabling the formation of complex shapes and thin walls). The metal forming method presented in this article involves thixoforging, where a semisolid is obtained by partial melting with a reduced liquid fraction below 20\%. But Püttgen (2007) defined this shaping zone as between 10 and 25\% of the liquid fraction. Previous studies have largely focused on alloys with relatively low melting temperatures and with easy heating conditions, where the liquid fraction of a semisolid is not highly sensitive to variations in temperature. The focus of such studies has also been limited to geometries meeting conventional forging forming criteria. For a more frequently use of thixoforging in the industry must do research to improve the knowledges of the field of application and the limits of this process in terms of possibilities of shaping materials, accessible geometries and product qualities, structural and mechanical.

Thixoforging of a tubular part is investigated in this paper. Unlike complex shapes, this geometry limits difficulties associated with analysing material flows and, in this case, the flow involves extrusion. This simple geometry enables investigations of more elementary material flows via forging tooling and the influences of the direction of shaping and forward and backward extrusion according to the tool used. It simultaneously allows constraints and specificities of forming related to the thixoforging, among others constraints, to be investigated. However, this simple a priori 
shape cannot be obtained easily through conventional forging because of certain dimensional and geometric requirements.

In the spirit of defining certain limits for the application of steel thixoforging, an SAE1006 lowcarbon-percentage steel grade of steel was used and studied. It is noteworthy that the semisolid forging of such low-carbon steel grades was never studied in the literature. For a particular alloy grade to be used at the semisolid state for forming, knowledge of its melting and solidification kinetics enables the design of heating cycles to reach the semisolid state of the alloy to a targeted liquid fraction. Unfortunately, it is difficult to establish the melting and solidification kinetics accurately because the heating rates of the induction furnaces used for experiments are very high compared to that of differential scanning calorimeters usually used to determine the liquid fraction at a given temperature. The determinations of liquid-solid fraction curves as a function of temperature by differential thermal analysis (DTA) are typically carried out at low heating rates (from 20 to $50{ }^{\circ} \mathrm{C}$ per minute according to installations). Hirt et al (2006) presents the DAT results for different steels grades generally studied in the literature. In contrast, induction heating methods conventionally applied for thixoforging range from $100^{\circ} \mathrm{C}$ per minute to $900{ }^{\circ} \mathrm{C}$ per minute. Many authors have shown that the heating rate influences the liquid fraction evolution of an alloy and that there is no way to obtain a rigorous liquid fraction for large heating rates. Gu et al. (2015) (2014) had studied the liquid fraction evolution at high heating speeds but for specific steel grades such as M2 that are not commonly used in the forging industry. At a solid state, the carbides of M2 steel are visible and correspond on a percentage basis to the liquid fraction of the semisolid alloy. Therefore, for the remainder of this article, given current difficulties associated with accurately determining the liquid fraction, only the heating temperature of the billet and its steel grade are given and the liquid fraction is evoked in an indicative manner. The reader can easily note that thixoforging is performed at a liquid fraction of less than $20 \%$ according to DTA curves, corresponding to numerous guidelines listed in the literature. Hirt et al. (2006) showed that shaping by thixoforging should be carried out at liquid fractions between 10 and 20\%, whereas Cézard (2006) and Becker (2008) obtained good-quality parts using liquid fractions of less than $10 \%$, as was the case for the Thixofranc project (Bigot et al., 2013).

According to the kinetics of solidification, the use of low-carbon steel is not favourable for thixoforging. Furthermore, as others Cézard (2006), Winship (1978), Fischer (2008) and Lozares et al (2014) have shown, a lower carbon content results in a higher temperature of the semisolid domain of metal alloys and in a lower difference between the temperature of the solid and that of the liquid. Certain addition elements, even in small amounts, can improve the heating conditions of an alloy. Alloy modification patents demonstrating the improvement of the thixoforging of a steel grade have been established (2004). Rassili et al (2010) compares the C38 and C38LTT DAT this last one specially designed for shaping of semisolid state.SAE1006 steel has a low carbon content and includes no specific elements that can decrease the melting temperature and/or increase the temperature range between the solid phase and liquid phase, which means that for small variations in temperature, variations of the liquid fraction can be large, rendering the control of heating to obtain a precise liquid fraction difficult. Table 1 presents the melting temperature and temperature difference between the solid and liquid phase for SAE1006 steel compared to various steel grades used in research related to the shaping of steels in the semisolid state. 
Table 1.

Comparison of the solidus-liquidus domain and the melting start temperatures of different steels

\begin{tabular}{|c|c|c|c|c|}
\hline Steel Grade & $\begin{array}{c}\text { Carbon } \\
\text { percentage in } \\
\text { steel } \\
(\text { Mass \%) }\end{array}$ & $\begin{array}{l}\text { Melting start } \\
\text { temperature } \\
\left({ }^{\circ} \mathrm{C}\right)\end{array}$ & $\begin{array}{l}\text { End of } \\
\text { melting } \\
\text { temperature } \\
\left({ }^{\circ} \mathrm{C}\right)\end{array}$ & $\begin{array}{l}\text { Temperature } \\
\text { difference } \\
\text { between } \\
\text { solidus and } \\
\text { liquidus }\left({ }^{\circ} \mathrm{C}\right)\end{array}$ \\
\hline SAE1006 & 0.05 & 1456 & 1519 & 63 \\
\hline $\begin{array}{l}\text { HP9/4/30 } \\
\text { (Omar et al., n.d.) }\end{array}$ & 0.31 & 1430 & 1490 & 60 \\
\hline $\begin{array}{l}\text { SKD61 } \\
\text { (Yi et al., 2012) }\end{array}$ & 0.36 & 1318 & 1489 & 171 \\
\hline $\begin{array}{l}\text { C38 } \\
\text { (Rassili et al., 2006) }\end{array}$ & 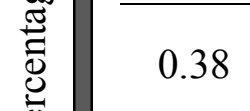 & 1430 & 1530 & 100 \\
\hline $\begin{array}{l}\text { C38 LTT } \\
\text { (Rassili et al., 2006) (Cezard et al., } \\
\text { 2007b) (Becker, 2008) }\end{array}$ & 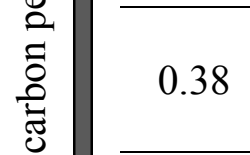 & 1380 & 1500 & 120 \\
\hline $\begin{array}{l}\text { C45 LTT } \\
\text { (Lozares et al., 2014) }\end{array}$ & 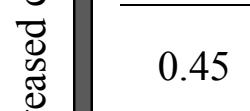 & 1360 & 1475 & 115 \\
\hline $\begin{array}{l}\text { C80 } \\
\text { (P. Cézard, 2006) }\end{array}$ & 0.8 & 1360 & 1485 & 125 \\
\hline $\begin{array}{l}\text { M2 } \\
\text { (Kopp et al., 2002) (Omar et al., } \\
\text { 2011) (Gu et al., 2012) }\end{array}$ & 0.85 & 1230 & 1455 & 225 \\
\hline $\begin{array}{l}\text { 100C6 } \\
\text { (P. Cézard, 2006) }\end{array}$ & 1 & 1275 & 1445 & 170 \\
\hline $\begin{array}{l}\text { X210CrW12 } \\
\text { (Mohammed et al., 2013) (Hirt et al., } \\
\text { 2005) }\end{array}$ & 2.1 & 1215 & 1405 & 190 \\
\hline
\end{tabular}

Some steel grades have temperature ranges between solidus and liquidus that are larger than others, making it easier to control a liquid fraction using a heating system. However, because of their characteristics, these steels often cannot be applied to forged parts. Tube thixoextrusion is expected to help defining the process windows and limitations for the thixoforging of steel grades with narrow solidus-liquidus temperature range.

This paper presents experimental test results on a low-carbon and low-alloy steel grade that is difficult to use for thixoforging. According to specific forming conditions, this approach makes it possible to

- validate the use of SAE1006 steel for thixoforging,

- validate dimensional and geometric conditions difficult to achieve via conventional forging,

- check the material flow and its macrostructure and microstructure.

\section{Selection of tube design, materials and processes}

\subsection{Tube design and material}


This part obtained by thixoextrusion has been described by various authors. Hirt et al (2005) used this process to shape in the semisolid state via the rheoforging of 100C6 stainless steel.

To study the effects of material flows on of thixoforging results, we created tubes of identical size and mass in two different extrusion directions (forward and backward), which may correspond to industrially forged products. Certain selected dimensional and geometrical conditions associated with the production of tubes are difficult to obtain by conventional forging in a single step (e.g., the wall thickness with respect to the outside diameter or the internal clearance angle). Figure 1 illustrates these dimensions.

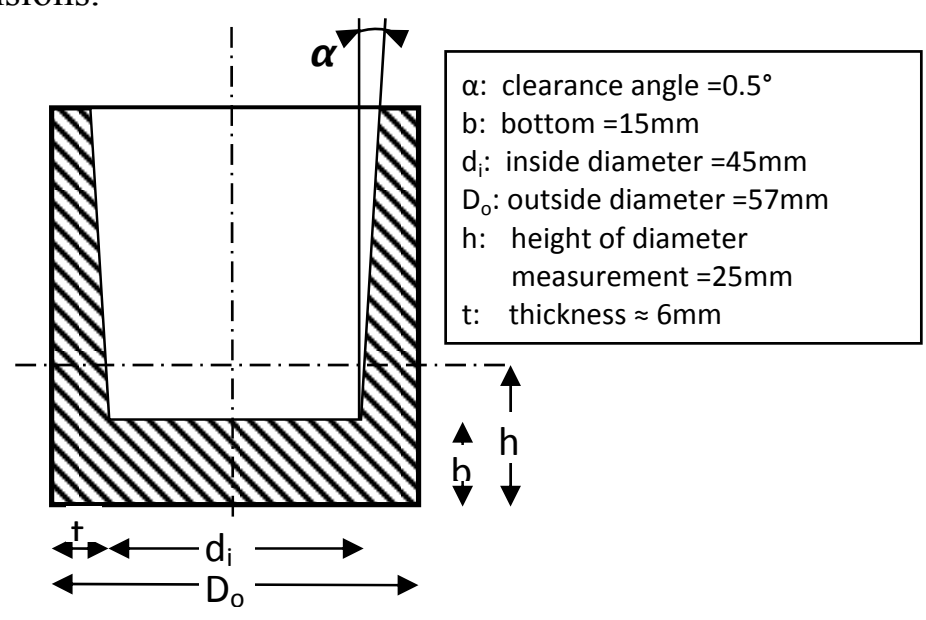

Fig. 1. Dimensional and geometric test tube characteristics.

The volume of the billet (diameter $45 \mathrm{~mm}$ and height $60 \mathrm{~mm}$ ) is defined according to the dimensions of the tubes chosen; it corresponds to a mass of $750 \mathrm{~g}$. These characteristics take into account the means available on the experimental platform (e.g., heating power or press forming energy) as well as the need for sampling for analysis.

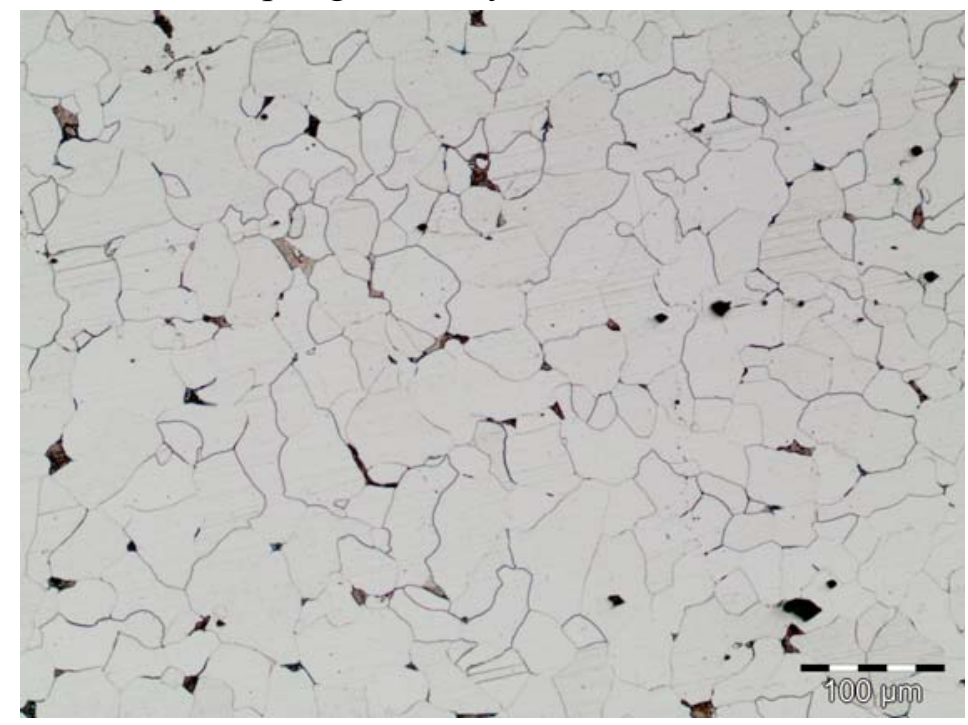

Fig. 2. Microstructure of the SAE1006; raw from fed stock before the thixoforging process ASTM 7 [27-32] $\mu \mathrm{m}$.

The microstructure of the initial alloy (Fig. 2) consists of equiaxed grains with a homogeneous size distribution centred at approximately $30 \mu \mathrm{m}$. The SAE1006 grade composition is detailed in Table 2.

Table 2.

Chemical composition of commercial SAE1006 low-carbon steel used in the experiments; mass \%.

\begin{tabular}{cccccccccc}
\hline $\mathrm{C}$ & $\mathrm{Mn}$ & $\mathrm{P}$ & $\mathrm{S}$ & $\mathrm{Si}$ & $\mathrm{Al}$ & $\mathrm{N}$ & $\mathrm{Ni}$ & $\mathrm{Cr}$ & $\mathrm{Cu}$ \\
\hline 0.053 & $\ldots$ & 0.022 & 0.008 & 0.184 & - & - & - & 0.06 & - \\
\hline
\end{tabular}


The semisolid fraction evolution of the steel as a function of temperature was determined using the THERMOCALC ${ }^{\circledR}$ programme following the Scheil-Gulliver model (calculation of solidification) as a function of the chemical composition (Table 2). From the results of the solidification calculations, the liquid fraction curve as a function of temperature (Fig. 3).

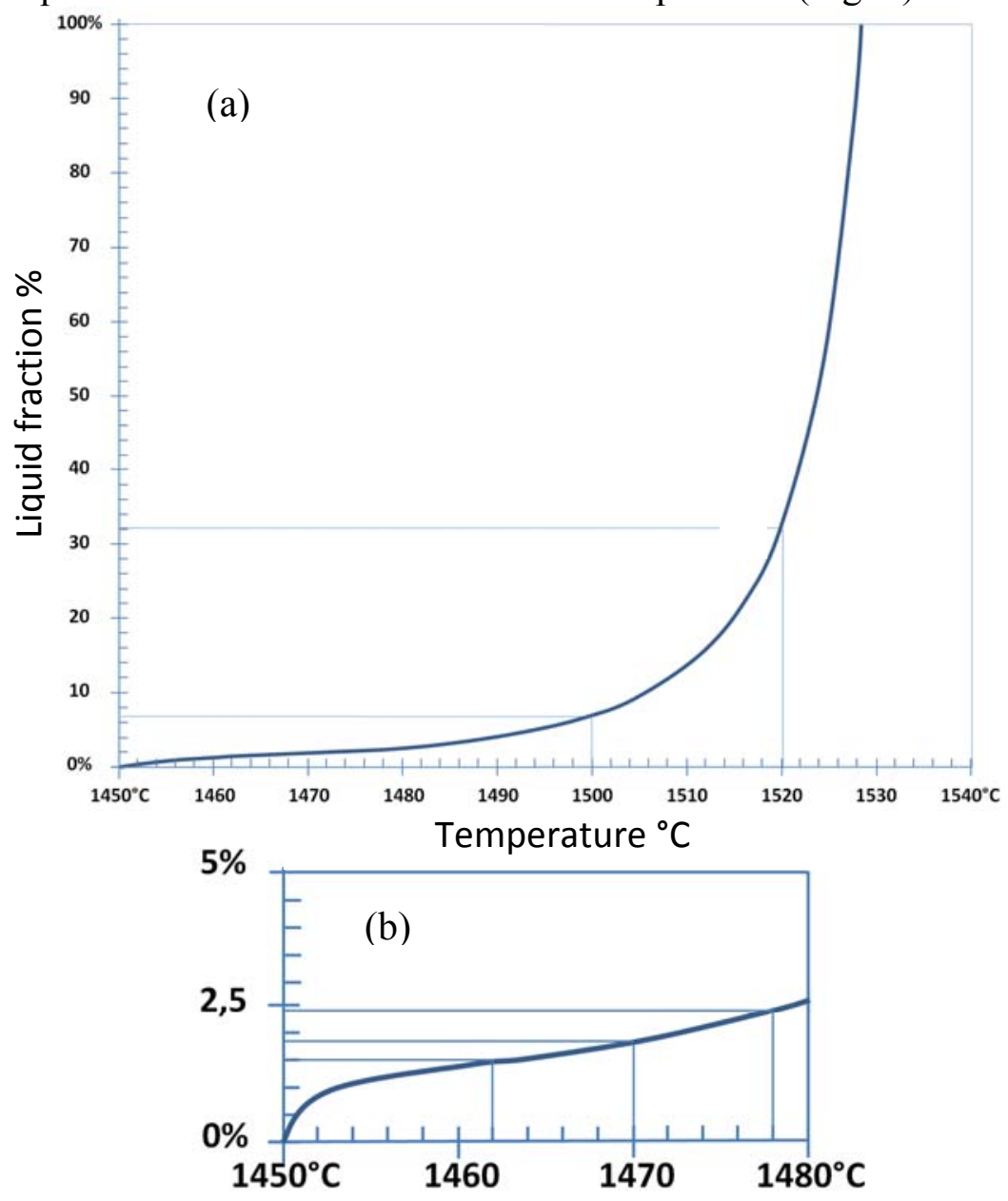

Fig. 3. (a) Liquid fraction curve obtained from the calculation of solidification results obtained using ThermoCalc ${ }^{\circledR}$ for steel SAE1006; (b) an expanded view of the temperature range used in this study.

According to these calculation results, a temperature of $1520{ }^{\circ} \mathrm{C}$ is required to obtain a liquid fraction of $32 \%$. After $1520{ }^{\circ} \mathrm{C}$ is reached, a minor temperature increase results in rapid variations of the liquid fraction; for example, the temperature $1520{ }^{\circ} \mathrm{C}$ corresponds to a $32 \%$ liquid fraction, whereas at $1500{ }^{\circ} \mathrm{C}$, the liquid fraction is only $7 \%$. This extreme variation in liquid fraction means that the heating requirements of this material are greater than those of steels used in previous thixoforging experiments, as shown in Table 1.

\subsection{Forming process}

Forming tests should enable the study of the effects of both materials and material flows. Tube extrusion can be carried out in two directions of material flow (forward and backward) with respect to the direction of tool movement (here a punch). These two processes lead to parts of identical volume and morphology, while involving different heat transfers and friction histories. Figure 4 illustrates these two variants of the extrusion process. 


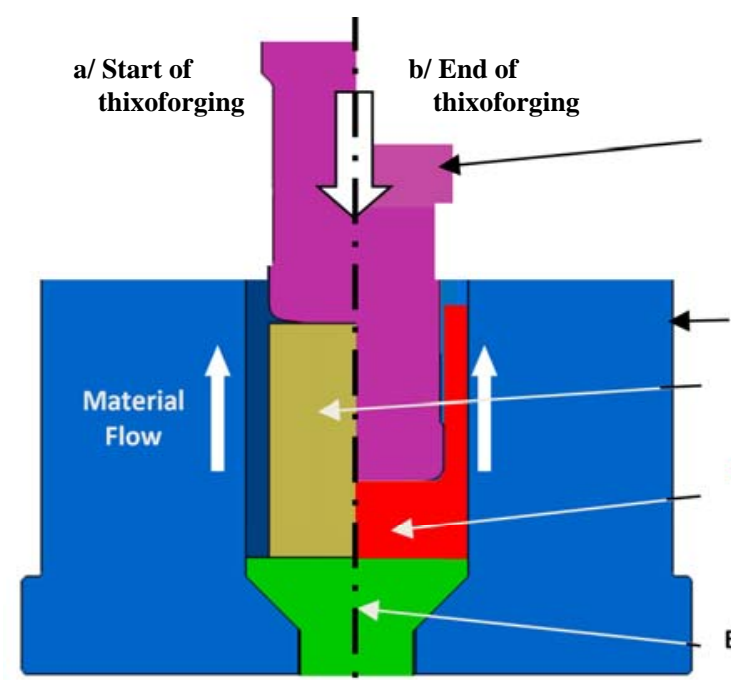

Backward thixoextrusion

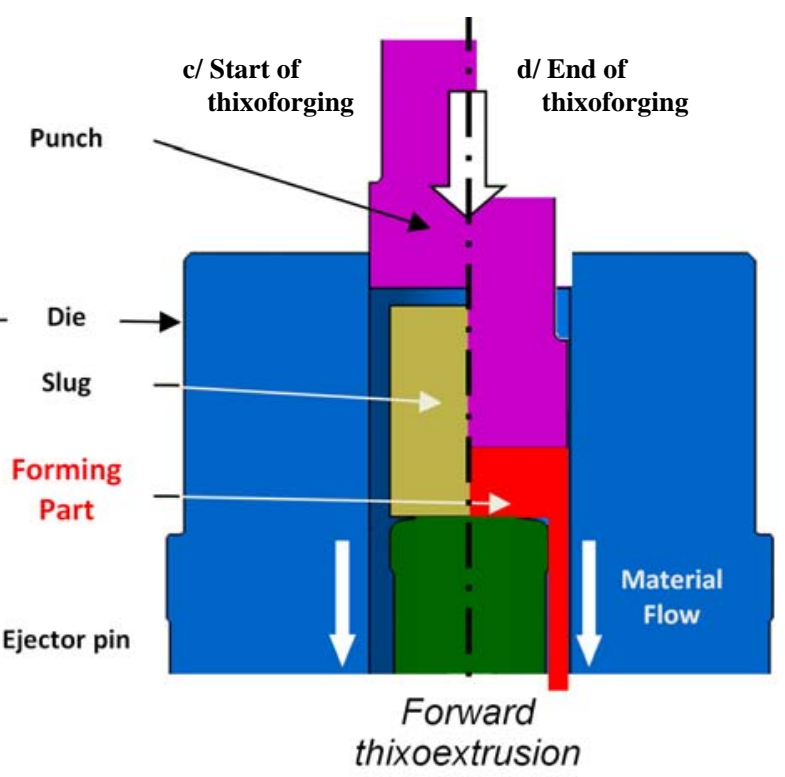

Fig. 4. Illustration of the alloy flow in the semisolid state with respect to the punch: fixed in the forward direction and mobile in the backward direction.

\section{Experimental method}

Experimental means must meet the constraints and specifications of metal alloys shaped in the semisolid state. According to recommendations from Becker et al. (2010), for the steels examined in this study, these constraints and specifications include high shaping rates (greater than 300 $\mathrm{mm} / \mathrm{s}$ ), heating of the tooling, and control the billet temperature both in the furnace and when steels are transferred to the shaping matrix.

Forging was carried out on the Vulcain platform of the Arts et Métiers of Metz (Fig. 5).

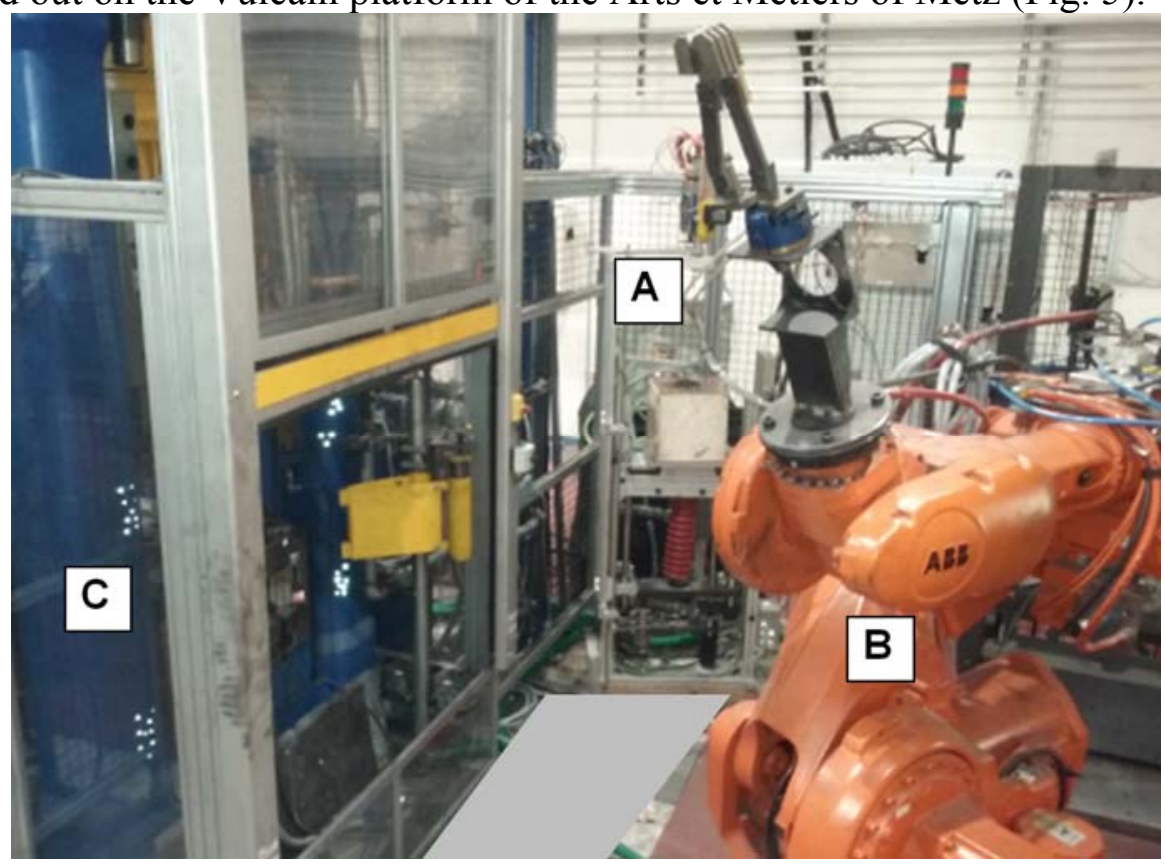

Fig. 5. Experimental thixoforging platform. A: heating cell; B: transfer robot; C: screw press. 


\subsection{Heating method}

For this project, an MP75 CELES induction furnace was used, capable of delivering $75 \mathrm{~kW}$ and powered by a generator that operated at a low frequency of $1400 \mathrm{~Hz}$. Billet temperatures measured before shaping must correspond to the semisolid temperature and must be as homogeneous as possible throughout the volume. However, a sufficiently resistant solid skeleton must be maintained; therefore, a solid skin temperature that allows the slug to be transfered from the oven to the press should be used.

The heating cell has been adapted to the diameter and to the height of the slug (Fig. 6). At high temperature, the steel forms very fast a mixture of several oxides stacked in a surface layer that constitutes the oxide scale. This layer, when introduced with the hot billet in the tool, causes the premature wear of forging tools and generates greater shaping forces. To prevent metal oxidation during heating, oxygen present in the heating cell must be rarefied. Oxidation is reduced by injecting a rare non-oxidizing gas into the closed enclosure containing the inductor and slug to be heated, as is done for other existing installations. Hirt et al. (2005) and Bigot et al. (2013) used such solution in their experiments to improve the result of steel thixoforging.

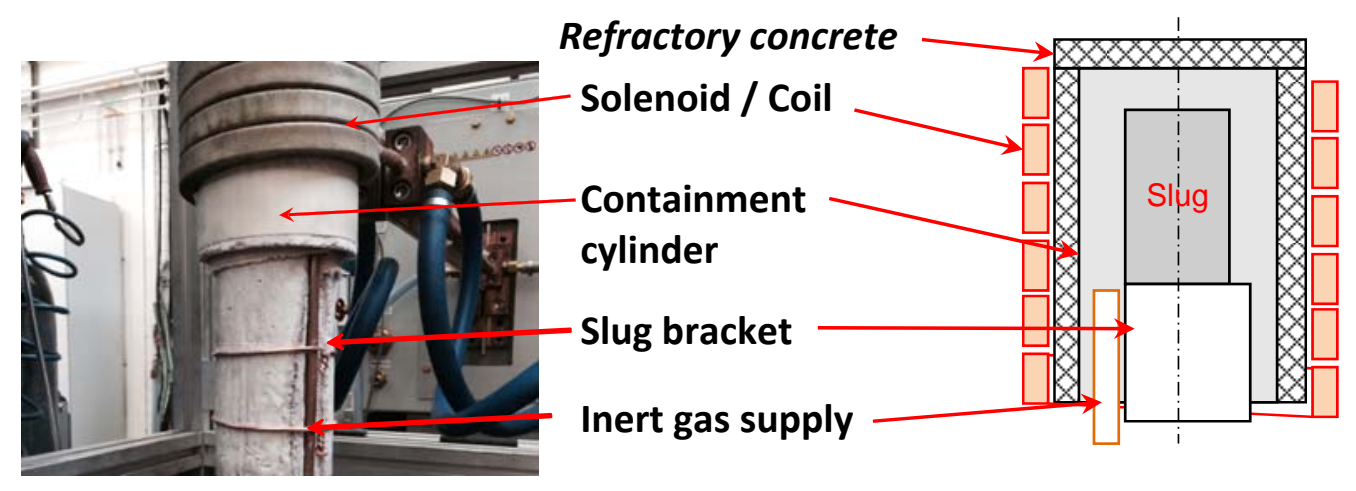

Fig. 6. Heating cell.

\subsection{Development of heating cycles}

The objective of the development of heating cycles is to achieve a controlled temperature gradient in the billet that is as homogeneous as possible, allowing the uniform flow of the material during shaping with minimal stress and a lower forging force. Heating cycle optimization must enable this homogeneity condition to be satisfied for temperatures over a total heating time of less than 3 min. This maximum heating duration is defined according to industrial requirements and according to experiments already carried out under these conditions. To respect the production rate in Thixofranc project, Bigot et al. (2013) had to use a inductive furnace with 16 cells. This shortened time makes it possible to respect industrial rates and to limit the oxidation of hot steel, which becomes excessively oxidizable at these temperatures and heating rates.

When developing heating cycles, three S-type thermocouples (platinum/platinum-rhodium) are placed in the following positions: one in the centre, the second in the mid-radius and the third in the position closest to the billet skin. This heated billet is only used for heating cycle adjustments and is not forged. The thermocouple arrangement must provide sufficient information to interpret the temperature evolution of various areas of the semisolid billet and, thus, to locate the extent of the penetration depth of electromagnetic fields of the induction furnace.

Figure 7 shows the dimensions of the billet and the thermocouple positions in the volume. 

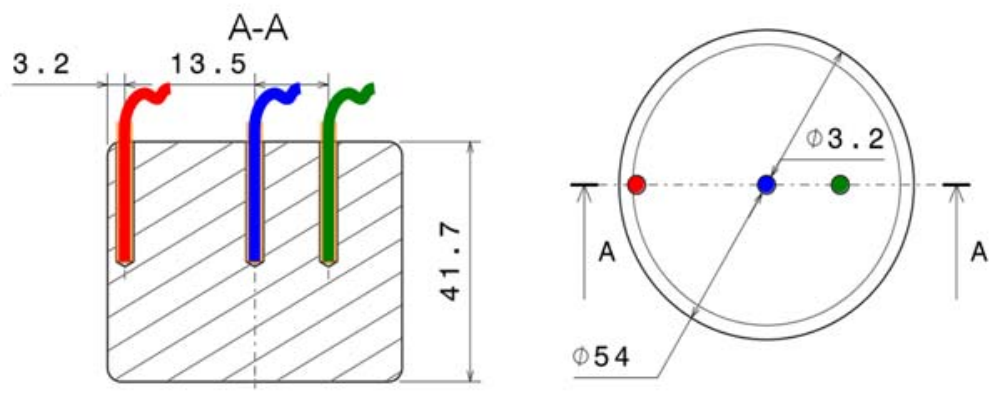

Fig. 7. S-thermocouple positions in the billet used for the development of the heating cycle.

\subsubsection{Development principle of the heating cycle}

The first heating and forging tests were carried out with C38 LTT steel. Becker (2010) and Lozares (2014) been used this steel grade with good results and so it was decided initially, for the development of tests, to use this last one.. In the next paragraphs, the method for developing the heating cycle of C38 LTT steel is described; this method can be transposed to SAE1006 low-carbon steel through various adjustments.

The main objective of our heating tests of C38 LTT steel is to achieve a temperature close to 1420 ${ }^{\circ} \mathrm{C}$ that is as homogeneous as possible in the billet volume and with a furnace stopping time of approximately $8 \mathrm{~s}$ at the end of the cycle. This waiting time without a heating input power must be included because it corresponds to the robotic transfer time between the furnace and the forging tool; however, it also makes it possible to homogenize temperatures in the billet volume through the internal thermal phenomenon of conduction because the frequencies of the induction furnace do not act equally on the billet. Behrens et al (2004), Hirt et al. (2005) and Becker et al. (2010) have has been used by other researchers in various experiments this heating cycle control method has been used by other researchers in various experiments. This cycle heating must be adapted to specific dimensions, materials and temperature conditions.

Figure $8 \mathrm{a}$ shows the temperatures measured by the three thermocouples during heating and subsequent cooling of the slug and the end of the heating period corresponding to the instant $126 \mathrm{~s}$. The black-coloured curve represents the power set point in kilowatts according to two heating stages. 

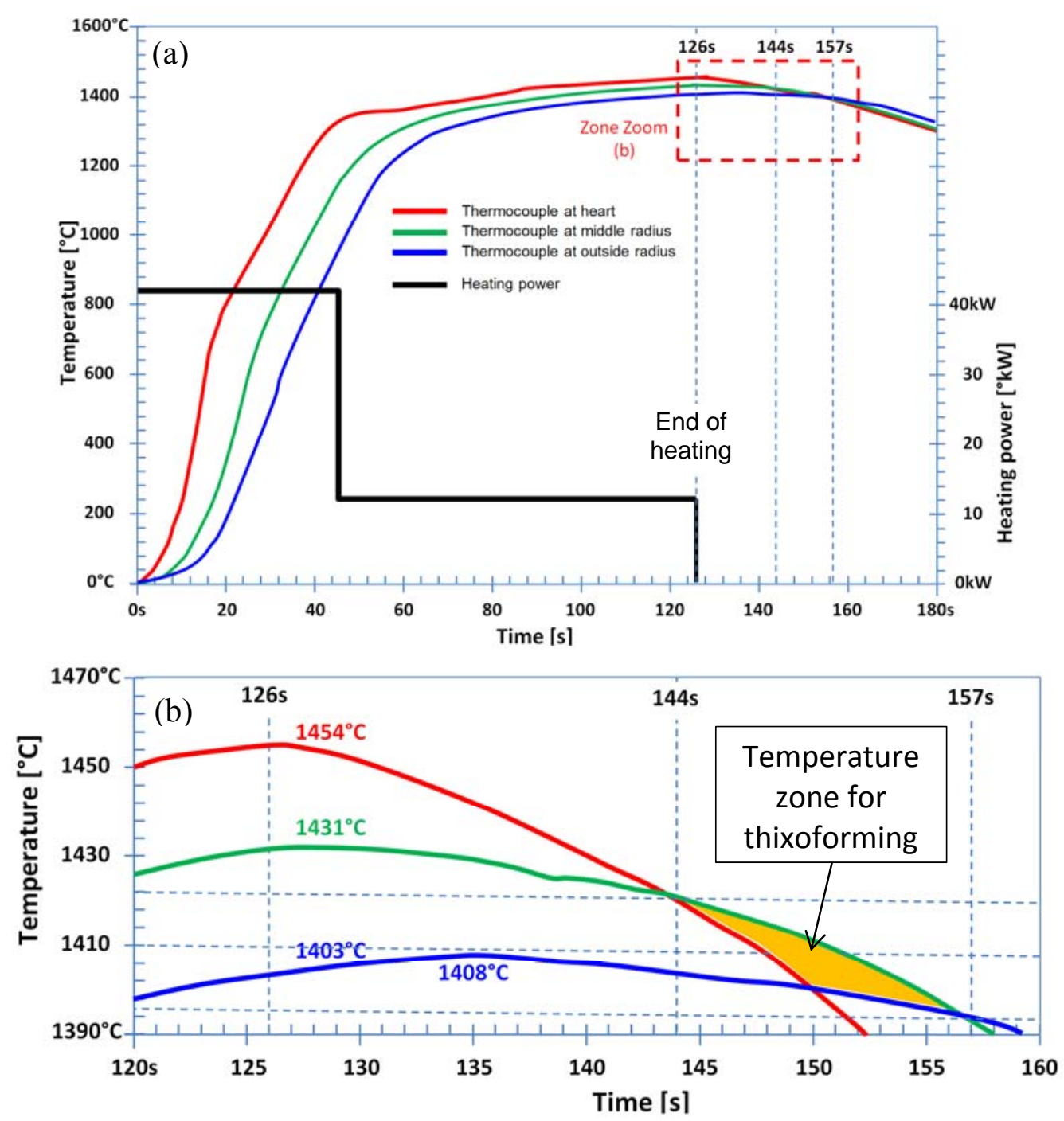

Fig. 8. (a) Heat cycle that was allowed to reach a core temperature greater than $1400{ }^{\circ} \mathrm{C}$ during heating of C38 LTT Heating. (b) Visualization of the three temperatures reached by the end of the heating period.

The temperatures obtained at the end of the heating period at $126 \mathrm{~s}$ were $1428 \pm 25.5^{\circ} \mathrm{C}$ with a maximum of $1454{ }^{\circ} \mathrm{C}$ in the skin, with no partial melting or apparent oxidation of the billet. At 144 s (i.e., $18 \mathrm{~s}$ after heating had stopped and $10 \mathrm{~s}$ after the minimum time required to transfer the slug), temperatures between the skin of the slug and the mid-radius were homogeneous at $1420^{\circ} \mathrm{C}$ and the temperature of the heart from the billet was $16{ }^{\circ} \mathrm{C}$ lower than that of the other two measuring positions. From this point and for $6 \mathrm{~s}$, the homogeneity of the temperature in the slug facilitates a uniform material flow during shaping. After this period, slug cooling occurred by convection and radiation, the skin temperature decreased rapidly and the liquid fraction in the material decreased. According the results (Fig. 8b), thixoforging is preferably carried out between $144 \mathrm{~s}$ and $150 \mathrm{~s}$ because, within this range, temperatures are the most homogeneous inside the volume and are closest to the target temperature of $1420^{\circ} \mathrm{C}$.

\subsubsection{Adaptation of the heating cycle to SAE1006 steel}

For the development of heating cycles of the SAE1006 steel billet, the same procedure as that used for C38 LTT steel is applied. According to the ThermoCalc ${ }^{\circledR}$ results related to solidification kinetics (Fig. 3a), the liquid fraction used in this study is approximately $2 \%$ for a temperature of $1470^{\circ} \mathrm{C}$. The slug is heating during $112 \mathrm{~s}$. After $7 \mathrm{~s}$ heating stopping, the temperature between the skin and the middle radius was homogeneous at $1480{ }^{\circ} \mathrm{C}$ and differed by more than $10{ }^{\circ} \mathrm{C}$ from the centre temperature (Fig. 9). This time is corresponding approximately at transfer time. From this point and 
for $6 \mathrm{~s}$ onward, a homogeneous temperature of $1472 \pm 78{ }^{\circ} \mathrm{C}$ is obtained in the billet. Within this range, the calculated liquid fraction ranges between $1.6 \%$ and $2.4 \%$ (Fig. $3 b$ ).

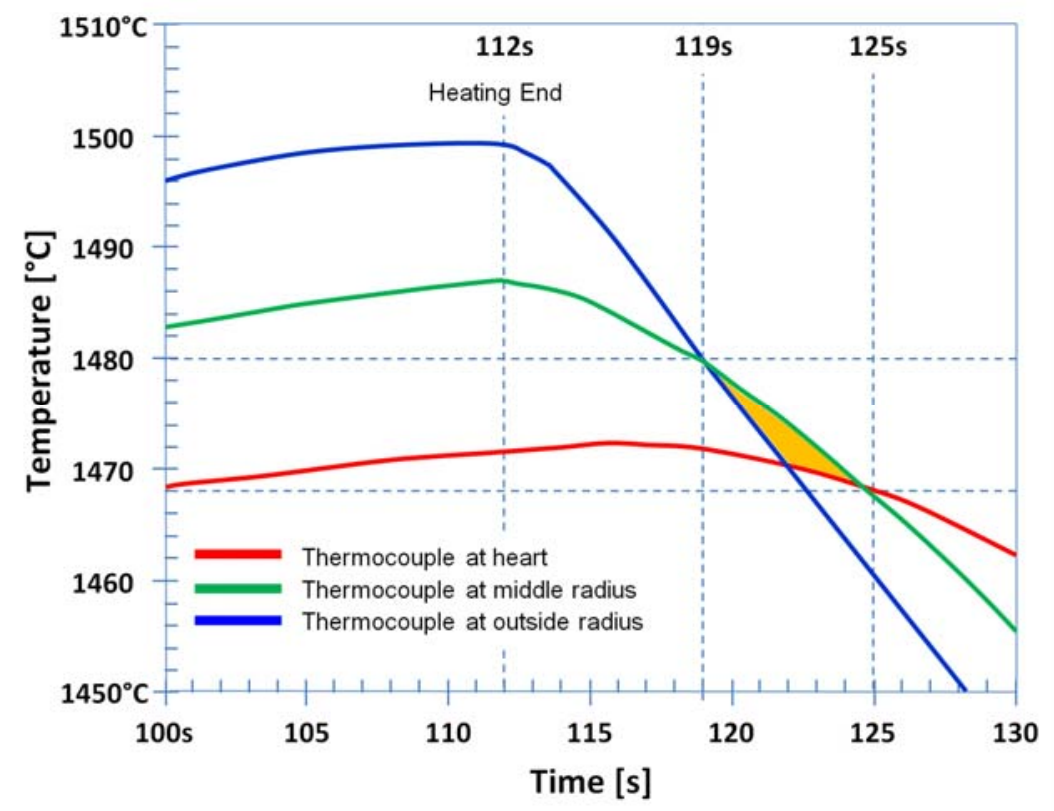

Fig. 9. Visualization of the three temperatures reached by the end of the heating period of SAE1006 steel.

The SAE1006 material can be heated 14 s faster than C38 LTT steel. However, the liquid fraction values calculated under thermodynamic and chemical equilibrium conditions without taking into account the initial microstructure cannot reveal actual percentages of liquid at such high heating rates. Consequently, this approach serves as a working basis for shaping this steel grade in the semisolid state.

The results obtained using the installed equipment and the developed heating cycle are satisfactory. The high homogenization speed of temperatures observed in the billet serves as an advantage for the shaping purposes. Additionally, under such conditions, greater heating power can be applied to the billet without increasing temperature heterogeneity, thus enabling the total duration of the heating cycle to be reduced.

\subsection{Transfer method}

Billet transfer from the induction heating system to the thixoforging tools placed in the screw press is ensured by a 6-axis ABB robot type 7600 255-500 with gripper tongs. The goal is to achieve repeatable transference to maintain controlled temperature variations between the furnace and shaping dies, thereby preventing the transfer time from influencing the analysis results.

The transfer system can be improved using a gripper system in a specific enclosure, enabling it to be placed in a neutral gas atmosphere that limits the oxidation of the billet at high temperatures during this phase.

\subsection{Tool method}

To obtain a tube by thixoforging, different shaping solutions can be applied. The production of a tube-type reference part, the dimensions of which are representative of real parts that can be shaped industrially, must provide information about the forming constraints and mechanical behaviours of the given part and tool. Such a process must also allow the influence of the direction of flow of a given material with respect to tools (forward and backward) on shaping forces, geometrical results and any associated defects to be assessed. 
To obtain parts of desired dimensions, tool sizing must consider the linear thermal expansion coefficients of the tooling steel and billet $\left(12 \times 10^{-6} \mathrm{~mm} \cdot \mathrm{K}^{-1}\right)$ according to a temperature variation of $1400{ }^{\circ} \mathrm{C}$. To obtain a diameter of $57 \mathrm{~mm}$ at $20^{\circ} \mathrm{C}$, the hot $\left(1420^{\circ} \mathrm{C}\right)$ size is $58 \mathrm{~mm}$.

The tooling material must meet cost and wear requirements. Cezard et al. (2007) present the high thermal stress resulting from the temperature difference between the semisolid billet and tool. Many authors, Aqida et al (2009), Hirt et al (2005), Khizhnyakova et al. (2010) and Püttgen et al (2004) have used ceramic tools or specific treatments to limit this stress. Unfortunately, such measures are expensive and can be used only under specific conditions (e.g., limited shocks), thus creating variations in forging velocities. The economic concerns regarding the viability of this process have led Bigot et al. (Bigot et al., 2013) through collaborations with several industrial partners via the Thixofranc project, to verify that the use of a tool material recognized by the forging industry can meet the severe shaping requirements for the thixoforging of steels. The outcomes of the use of X38CrMoV5 steel for tooling for the thixoforging of 10,000 pieces of steel grade C38 LTT, for which 3,000 parts were carried out without interruption, were found to be conclusive: the wear corresponds to that observed for conventional hot forging, thus allowing us to validate the use of this material for future purposes, as it corresponds to costs and mechanical resistance criteria followed by industrialists. Tool steels such as W-Nr 1.2342 and $\mathrm{W}-\mathrm{Nr} 1.2365$ have been successfully used by Lozares et al (2012) for the thixoforging of automotive-type parts as well as by other researchers Rassili et al. (2004). In the latter cases, the limited number of parts produced could not verify the wear resistance of the materials used.

On the basis of previous LCFC results and the literature, we used X38CrMoV5 steel for tooling in this project.

\subsection{Forming method}

As forging method for these tests, we used a Lasco SPR400 screw press at Arts et Métiers in Metz; this press can create energy levels of $31.5 \mathrm{~kJ}$ at a maximum speed of $680 \mathrm{~mm} / \mathrm{s}$. As Becker et al. (2010) has shown in previous studies, the forming speed is a driving and essential parameter of thixoforging. Screw presses are also used when press speeds are high and when variations are limited during shaping (e.g. between $640 \mathrm{~mm} / \mathrm{s}$ and $200 \mathrm{~mm} / \mathrm{s}$ ). These fast and relatively constant conditions of pressing speed make it possible to limit heat exchanges and variations in flows resulting from variations in speed and to improve the control of thixoforging. The shaping end does not correspond to the end of the movement of the press ram; the surplus energy is consumed by striking plates and by the rebound of the slide. The resulting final velocity is not zero, and it generates sufficient pressure to support die filling.

\section{Backward and forward extrusion simulations}

The feasibility of the forging tests with the available equipment was validated by numerical simulations carried out using the Forge ${ }^{\circledR}$ software. This process involved checking material flow, mechanical stress on the tooling, the gradients of temperature and the maximum shaping force. These simulations were also carried out to differentiate the back and forward forging.

The main data parameters used for the various numerical simulations are based on numerical and geometric models and on associated conditions under the envisaged experimental parameters. The choice of parameters values are outcome of previous simulations works of forging and thixoforging Becker et al. (2008) and (2010). These simulations do not take into account the liquid phase and use a Hansel-Spittel visco-plastic model for a high-temperature solid. They are as follows:

- $\quad$ Axisymmetric 2D simulations.

- Homogeneous billet temperature: $1450{ }^{\circ} \mathrm{C}$; temperature coiled to experiment.

- Tool temperature: $250{ }^{\circ} \mathrm{C}$.

- $\quad$ Material: XC05 steel (database Forge ${ }^{\circledR}$ ) similar at SAE1006 steel.

- Heat exchange; $10000 \mathrm{~W} \cdot \mathrm{m}^{-1} \cdot \mathrm{K}^{-1}$. 
- $\quad$ Lubrication: Graphite; $\bar{m}=0.3$.

- $\quad$ Press: screw press of $31.5 \mathrm{~kJ}$ maximum energy.

- $\quad$ Initial waiting time before forging: $0.45 \mathrm{~s}$.

- Hansel-Spittel material model.

$$
\sigma_{f}=A e^{m_{1} T} \varepsilon^{m_{2}} \dot{\varepsilon}^{m_{3}} e^{\frac{m_{4}}{\varepsilon}}(1+\varepsilon)^{m_{5} T} e^{m_{7} \varepsilon} \dot{\varepsilon}^{m_{8} T} T^{m_{9}}
$$

where $\sigma_{\mathrm{f},} \varepsilon$, and $\dot{\varepsilon}$ are the flow stress, equivalent strain and equivalent strain rate, respectively; $T$ is the temperature in degrees Celsius; $m_{1}$ and $m_{9}$ define the material's sensitivity to temperature; $m_{5}$ is the temperature-strain coupling term; $m_{8}$ is the temperature-strain rate coupling term; $m_{2}, m_{4}$, and $m_{7}$ define the material's sensitivity to strain; and $m_{3}$ is dependent on the sensitivity of the material to the strain rate. For the study case, the parameters used include $A=504,16 \mathrm{MPa}, m_{1}=-0.0019, m_{2}=-$ $0.097, m_{3}=0.141, m_{4}=-0.031, m_{5}=0, m_{7}=0, m_{8}=0$, and $m_{9}=0$.

\subsection{Thermal difference of the final tube between back and forward forging}

This paragraph shows the evolution of the temperature of the billet according to the forging direction. In a first step is illustrated, the impact of the contact surface of the punch, which is different according to the direction of shaping, on the temperature of the slug. Secondly, the slug temperature at the end of the forging period for the two directions of extrusion is observed. For simulations, heat exchanges by radiation are not considered. In addition, the forging takes only a tenth of a second, in a closed matrix, and under these conditions we have estimated that the contribution of heat exchanges by radiation is limited in comparison with the heat exchanges by conduction between the tool and the steel at high temperature. The slug temperature at the beginning of shaping is considered to be homogeneous in all its volume and equal to $1450{ }^{\circ} \mathrm{C}$ which is approximate to the reality.

According on the direction of shaping, the slug is not positioned in the tool in the same way:

- Backward extrusion: the billet rests entirely on the lower die corresponding to the outer diameter of the final tube, and material flows along the punch. The heat exchanges are distributed across the entire lower surface of the billet.

- Forward extrusion: the billet rests on the punch, and the contact surface is reduced because it corresponds to the inside diameter of the final tube. In this case, the steel flows along the fixed punch on which it rests.

Figure 10 shows the gradient temperature of a billet after a waiting time of $45 \mathrm{~s}$ for the hot billet on the positioning pad after the end of the heating cycle. The billet base undergoes more cooling in the backward extrusion direction because, in this case, the area of the heat exchange surface between the positioning pad and the semisolid is greater. This greater area means that at the forging time, the temperature gradient in the billet volume depends on the extrusion direction and that within this gradient, the flow of the alloy volume cannot be fully homogeneous without taking into account the geometrical effects of tools. This phenomenon is attributed to surface contact between the billet and tooling. 

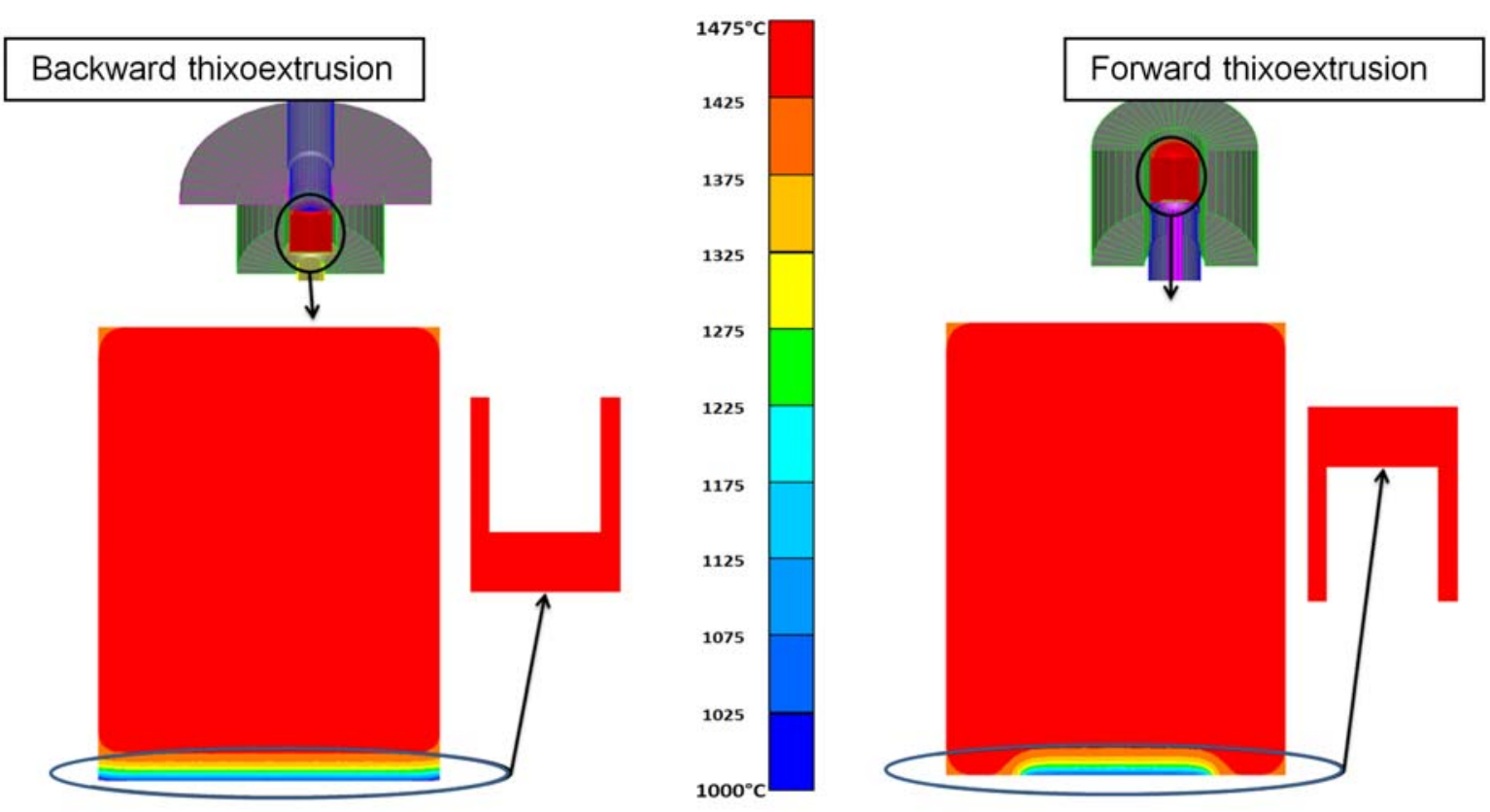

Fig. 10. Effects of tool contact on the billet temperature gradient before forging.

This difference in heat exchange surfaces can locally influence the flow of the alloy and the local microstructure of the tube in particular. This simulation can serve as an indicator of local observations.

Table 3 shows the evolution of the temperature at the end of the shaping period for the two extrusion directions. The temperatures between the dotted lines correspond to the pick-up zones of mechanical and/or metallurgical structure samples. The sampling area is the same for both shaping directions.

Table 3.

Temperatures simulated in the tube at the end of the forging period in backward and forward extrusion directions. 


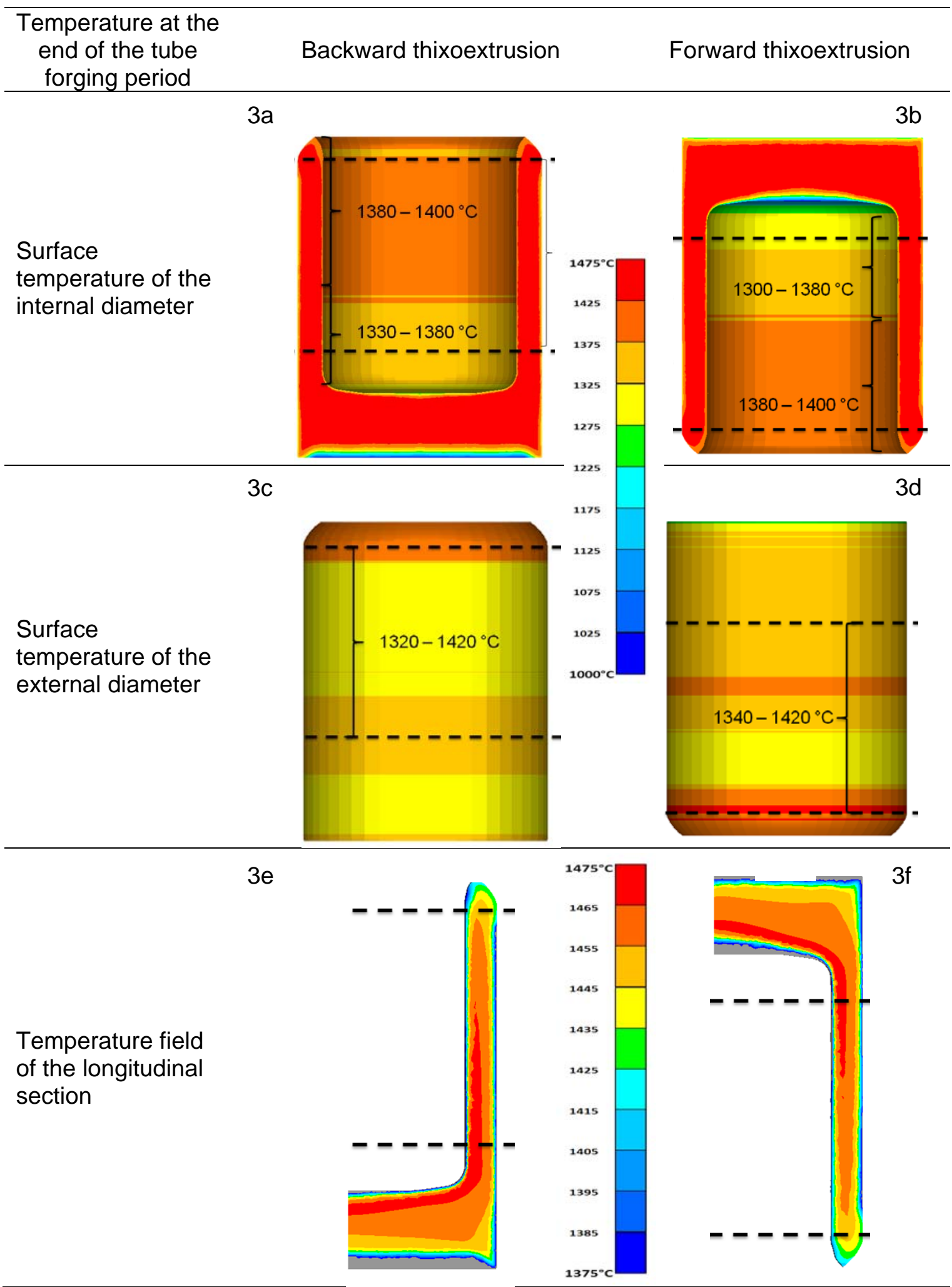

At the skin level of the inner bore (Fig. 3a and 3b), a slight temperature difference of approximately $10{ }^{\circ} \mathrm{C}$ remarkably exceeds the study height between the two extrusion directions. However, there are axial temperature variations for the two directions. The temperature is lower on the punch side, at 1330 to $1380{ }^{\circ} \mathrm{C}$, and ranges from 1380 to $1400{ }^{\circ} \mathrm{C}$ at the end of the tube. This axial temperature gradient must give rise to axial differences in the microstructures of the samples used in the experimental tests. However, they must also be similar in size and shape because of skin effects on the edges. 
Figures $3 \mathrm{c}$ and $3 \mathrm{~d}$ of Table 3 show the temperatures achieved on the outside diameter through the direct and indirect tube forging simulations, respectively. Between these two material flow directions, a slight difference of a few degrees is observed in the distribution of the axial temperature field $\left( \pm 20^{\circ} \mathrm{C}\right)$ on the outer surfaces of the tubes.

According to Figure $3 a$ and $3 b$, this temperature field is highly localized over a thickness of $0.1-0.3$ $\mathrm{mm}$. The temperature fields of the outside diameters are smaller than the temperature fields of the inside diameters; thus, the grain size must be slightly smaller. This slight difference in temperature can be explained by the difference in the heat exchange surface area.

Figure $3 \mathrm{e}$ and $3 \mathrm{f}$ show the temperature field in the longitudinal section of the tube as a function of the shaping direction. In the pick-up sampling area, the temperature distribution is almost the same between the two forging directions ( $T$ backward direction $>T$ forward direction of 5\% max). Temperatures of surfaces in contact with the tool that supports the billet tools are smaller than 1375 ${ }^{\circ} \mathrm{C}$.

These simulations also show that flows of the free surfaces at the ends of the tubes in both shaping directions are not planes perpendicular to the revolution axis. In both forging cases, material flow is easier along the punch and internal diameter than along the die outside diameter. Energy dissipated through friction along the punch of the flowing material is less important, explaining the higher degree of material axial displacement along the punch than along the external bore of the part.

The simulations did not reveal considerable differences between the two shaping directions. They show different local temperature gradients in the radial direction, the difference between the inner and outer radius, and the axial direction corresponding to the difference in the thermal exchange through contact with tools, both spatial and temporal. All of these results must be verified experimentally through a localized analysis of microstructures and macrostructures.

\subsection{Simulated forging force evolution}

Figure 11 shows the evolution of the simulated force as a function of the time of the backward extrusion of the XC05 (SAE1006) steel at various initial billet temperatures from 950 to $1470{ }^{\circ} \mathrm{C}$. The forging temperatures between $950{ }^{\circ} \mathrm{C}$ and $1250{ }^{\circ} \mathrm{C}$ correspond at hot forging temperature. In this simulation for all temperatures, the maximum forging force is less than the capacity of the screw press. In view of these results, it was possible to validate and authorize the experimental tests using the Vulcain platform. 


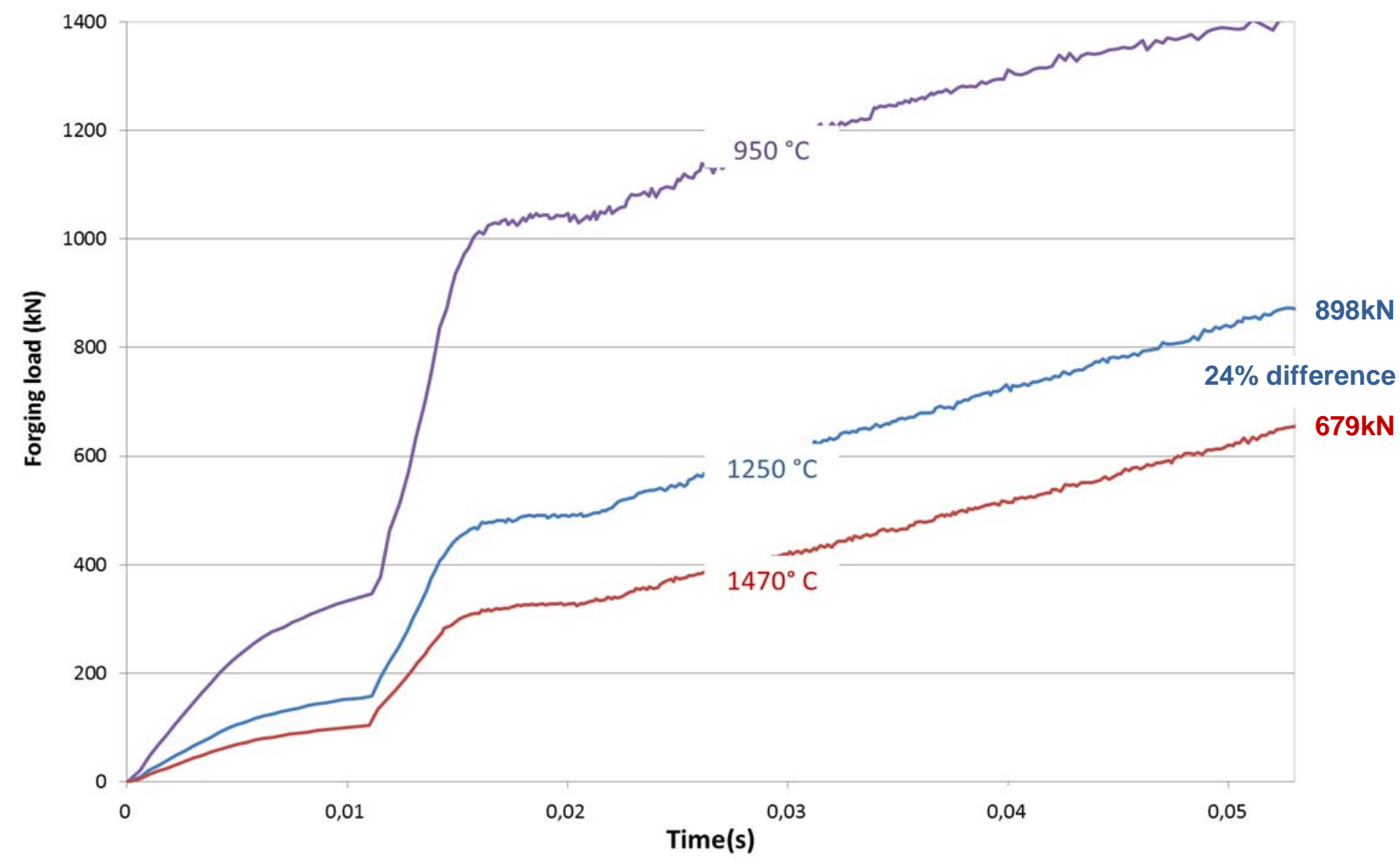

Fig. 11. Simulated forging force evolution as a function of the temperature of the deformed billet.

As expected, higher billet temperature resulted in lower forging forces. Remarkably, the effort gain is $24 \%$ for a temperature rise of $160{ }^{\circ} \mathrm{C}$ between 1250 , the highest hot forging temperature, and $1470{ }^{\circ} \mathrm{C}$, the used thixoforging temperature. For forward forging the results are similar. During forging time, what is not represented on these curves is the keeping closed die load obtained through springs. This holding force is approximately $500 \mathrm{kN}$.

\subsection{Simulation conclusions}

The simulations allowed us to validate the feasibility of our tests through backward and forward tube extrusion with a SPR400 screw press. They also reveal specific zones of cooling of the part at the end of forging, thus guiding the study of structures confirming or invalidating the size of local grains. In semisolid shaping case, the models associated at forging simulation software must still progress to give more precise information about the thixoforging load evolution and the toolmaterial interface.

\section{Experimental results}

More than 230 thixoforged parts were produced for this study (approximately 210 with C38 LTT steel and 24 with SAE1006 steel)

\subsection{Results of thixoforging experiments}

Figure 12 shows the evolution of the shaping force by thixoextrusion as a function of the time measured using the press force sensor. Two curves are shown in this figure: the first curve (red) is the simulated forging force corresponding to Figure 11 with holding force; the second curve (green) is the curve of forces measured during screw-press shaping. 


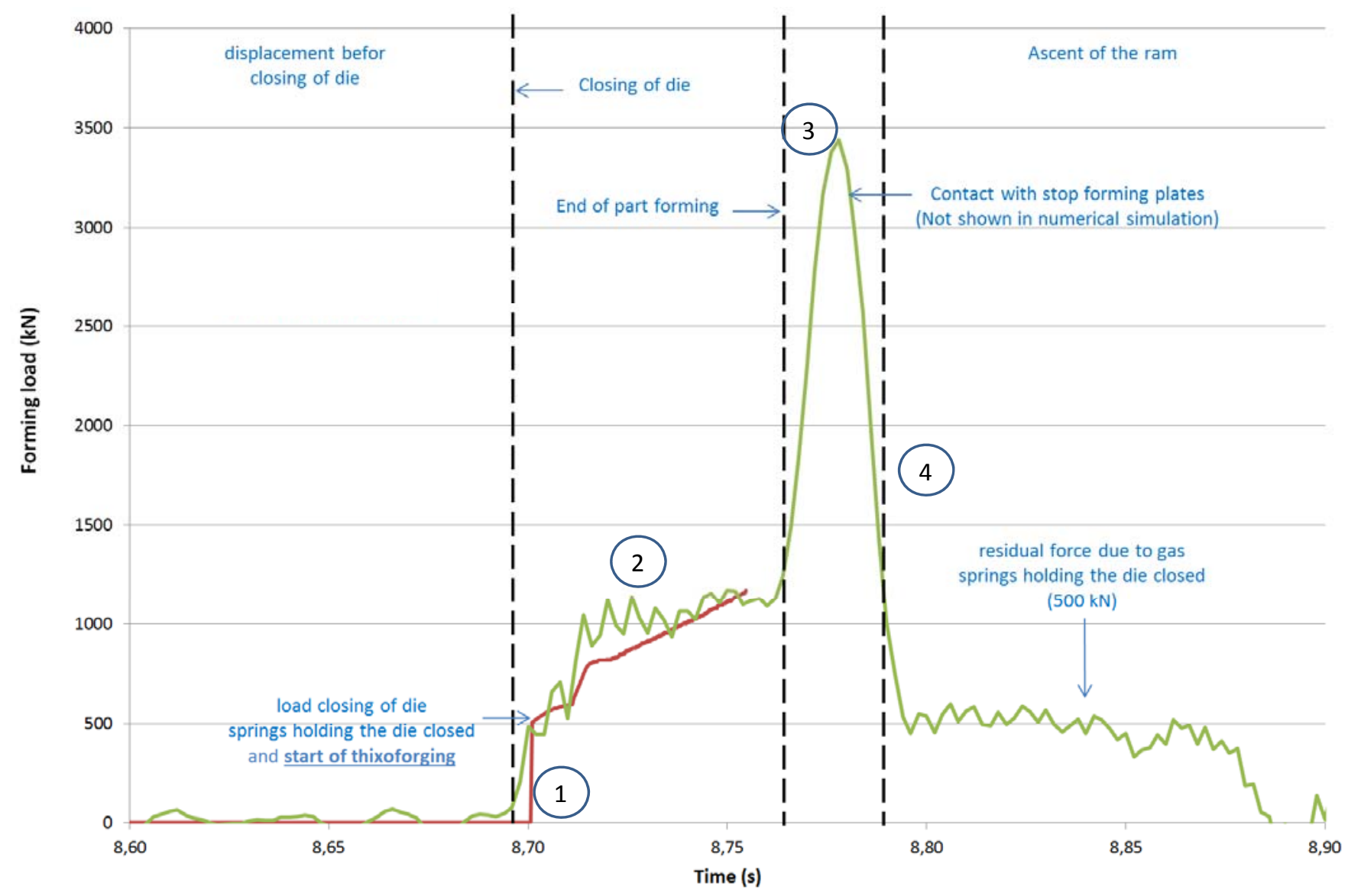

Fig. 12. Evolution of the shaping force by the thixoforging of produced tubes compared to the simulation results.

According to the measurements, the four major stages of shaping by thixoforging are:

- Tool closure is ensured by the compression of gas dampers; the simulation reflects reality, with differences attributed to the fact that closure efforts are not instantaneous in practice.

- Part shaping by thixoforging.

- The end of shaping and stopping press ram movement on wedges (until the bottom dead centre is reached); the ram of the press continues to move, the end of the shaping period does not occur at the bottom dead centre. This step is not simulated.

- The returns of the press ram to the top dead centre; from the bottom dead centre to the tool opening, the force of the damper gas is always measured.

Figure 12 is representative of the more than 250 tests carried out. During thixoforging, when comparing the simulation with the measurements, only the maximum shaping load is predictive. This information can be used to validate or not the use of a forging means according to its maximum capacities. The simulation associated with the Hansel-Spittle model does not provide precise information on the evolution of the load at each moment of thixoforging of a part. At some point there are load differences of almost $30 \%$ and the curves slopes are relatively different.

\subsection{Dimensional results}

Table 4 presents the tube measurements. 
Table 4.

Dimensional measurements of tubes created via thixoforging

\begin{tabular}{rccccc}
\hline & nominal & $\min$ & $\max$ & average & $\begin{array}{c}\text { standard } \\
\text { deviation }\end{array}$ \\
\hline $\mathrm{D}_{0}$ : outside diameter $=57 \mathrm{~mm}$ & $57 \mathrm{~mm}$ & 56.78 & 56.91 & 56.83 & 0.13 \\
\hline $2 \alpha$ : clearance angle & $1^{\circ}$ & 1.01 & 1.21 & 1.11 & 0.2 \\
\hline $\mathrm{d}_{\mathrm{i}}$ : inside diameter $=45 \mathrm{~mm}$ & $45 \mathrm{~mm}$ & 44.14 & 44.31 & 44.19 & 0.17 \\
\hline b: bottom $=15 \mathrm{~mm}$ & $15 \mathrm{~mm}$ & 15.44 & 17.01 & 15.87 & 1.57 \\
\hline
\end{tabular}

The dimensional results obtained by thixoforging via a single step using C38 LTT steel and SAE1006, in particular, are very satisfactory, generating dimensional diameter deviations of less than $0.2 \mathrm{~mm}$ and with clearance angles of approximately $1^{\circ}$. In addition, of the more than 200 forgings, the metrological control illustrated by standard deviations is less than $0.1 \mathrm{~mm}$, which is remarkable for a hot forging process.

The obtained average concentricity value is $0.65 \mathrm{~mm}$ with a minimum of $0.29 \mathrm{~mm}$ and a maximum of $1.26 \mathrm{~mm}$. The maximum roughness measured is $3.5 \mu \mathrm{m}$. The results are also dependent on billet oxidation levels during transfer from the induction furnace to the tooling and from the piece treatment after forming. To achieve good dimensional and geometric thixoforging capability, the appearance of oxidation on the part at higher temperatures must be controlled (Yukawa et al., 2014).

\subsection{Experimental results: Microstructure and macrostructure}

(a)

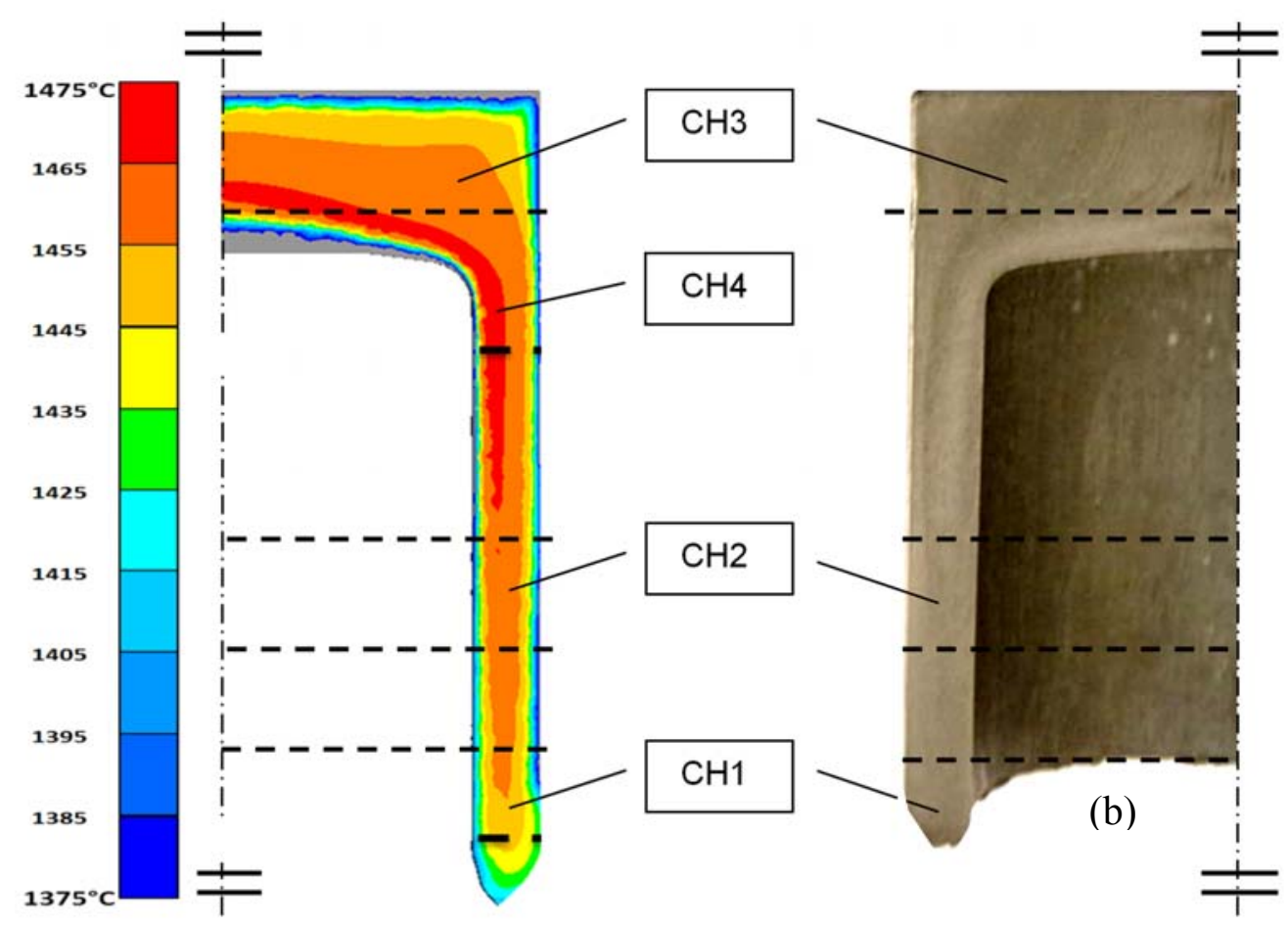

Fig. 13. Representation of the microstructure observation areas: (a) simulated temperature gradient at the end of the thixoforging period; (b) macrography of a tube. 


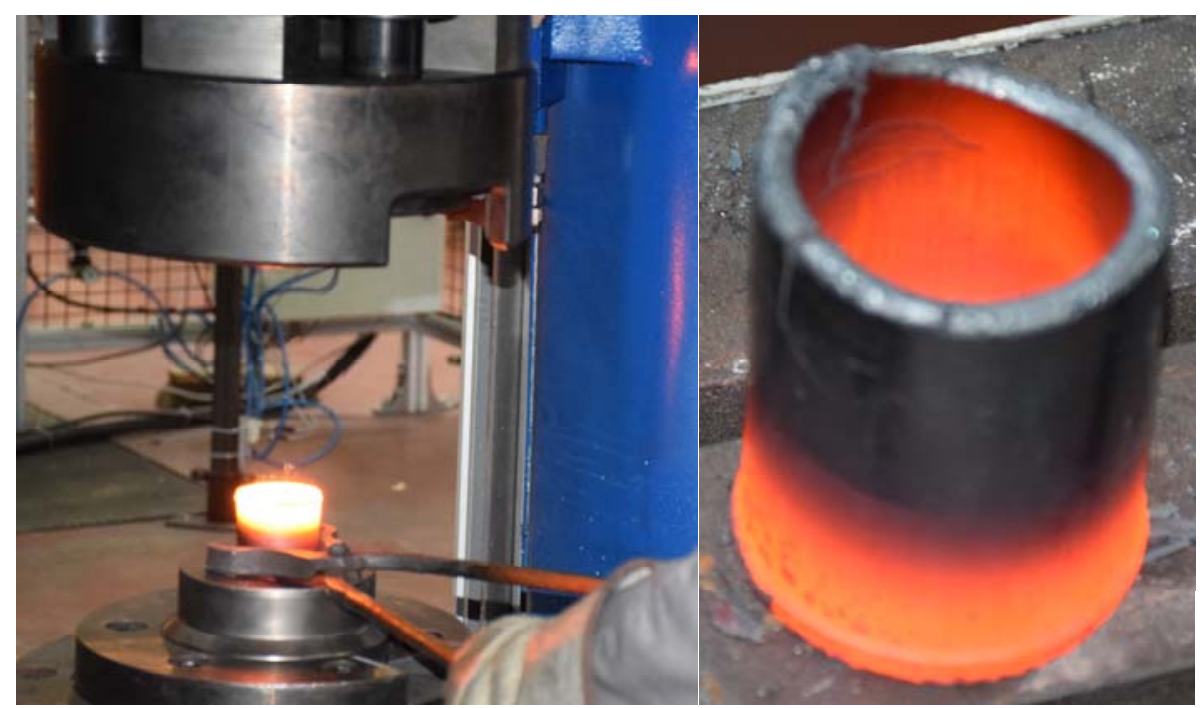

Fig. 14. Photographs of the thixforged part out of the tool.

Table 5.

Microstructures of an SAE1006 steel tube obtained by thixoforging

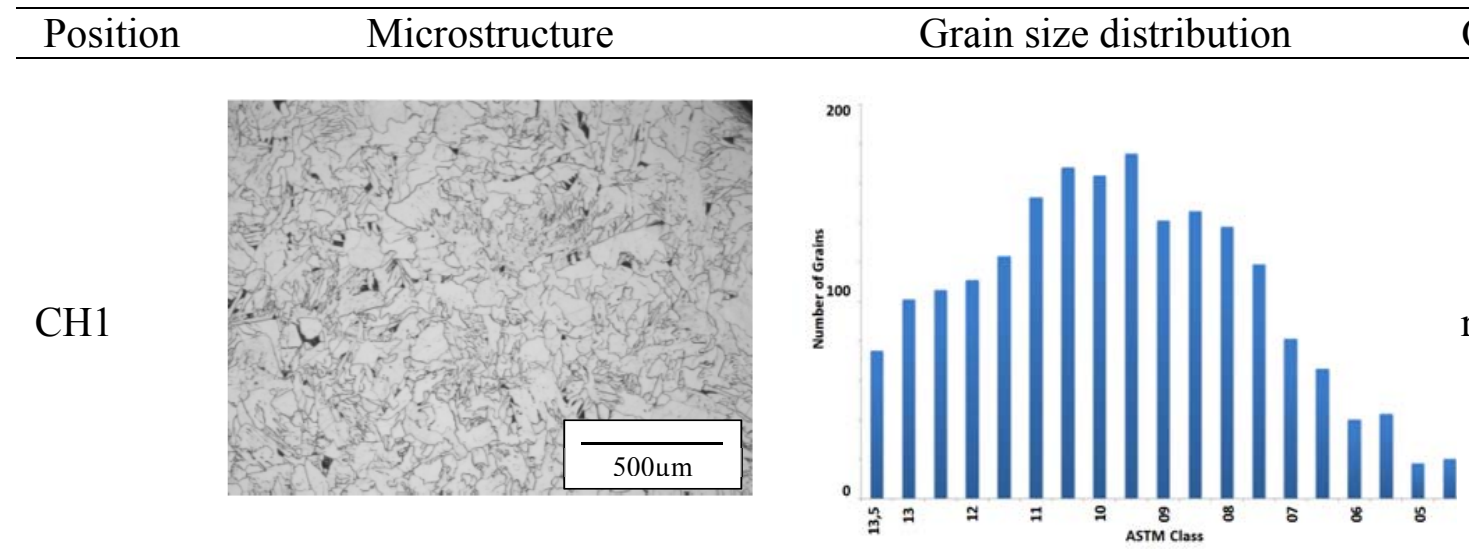
Characteristics
Gaussian

distribution

Grains of

elongated and

random shapes

ASTM 9.5

[13-11] $\mu \mathrm{m}$

$\max 100 \mu \mathrm{m}$

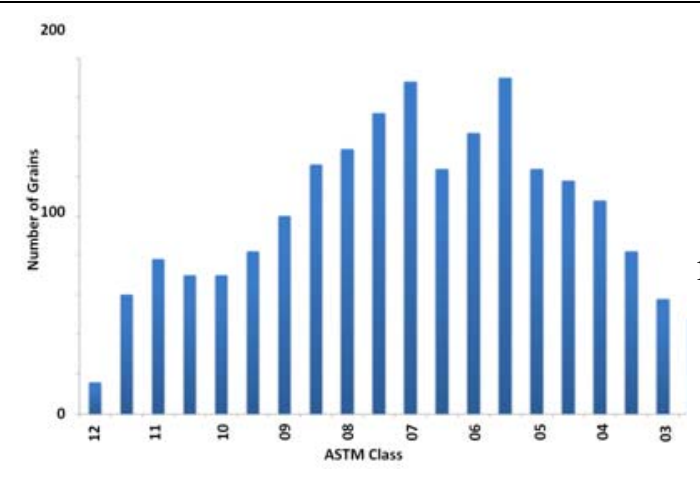

Gaussian

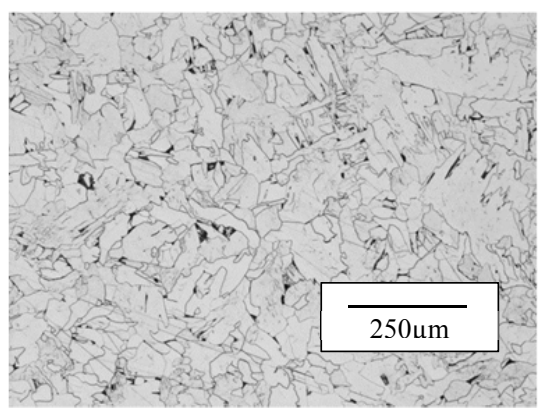

distribution

$\mathrm{CH} 2$

200

Grains of elongated and random shapes

ASTM 5.5

[53-45] $\mu \mathrm{m}$ $\max 300 \mu \mathrm{m}$

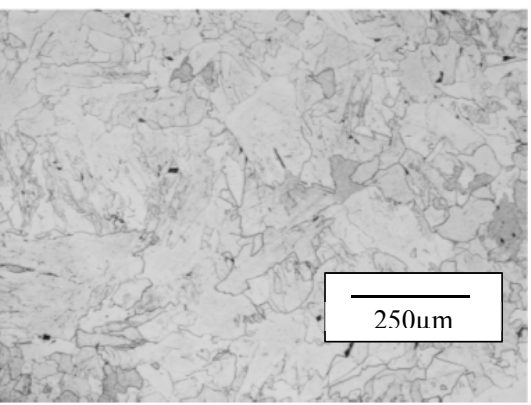

Tightened

Gaussian

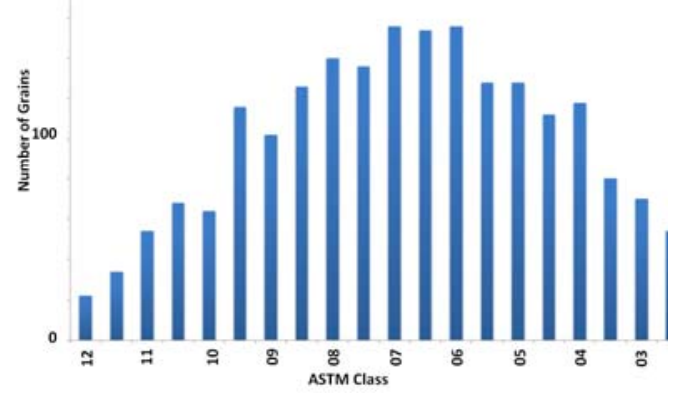

distribution

Grains of random shape

ASTM 6 [45-38] $\mu \mathrm{m}$ $\max 200 \mu \mathrm{m}$ 
Table 6 shows 3 micrographs of the cylinder, together with corresponding grain size distributions. The micrographs correspond to the respective $\mathrm{CH} 1$ (end of the cylinder), $\mathrm{CH} 2$ (centre) and $\mathrm{CH} 3$ (base of the cylinder) zones, (Fig. 13). The microstructure is ferritic and the shape of the grains remains identical in the 3 zones and in the entire cylinder. The grains are rather elongated and randomly shaped. However, as evident in Table 6, the grain size slightly varies along the height of the cylinder. The grain size distribution exhibits Gaussian behaviour, and the peak of this Gaussian curve moves towards larger grains from zone $\mathrm{CH} 1$ to zone $\mathrm{CH} 3$. At the end of the cylinder (zone $\mathrm{CH} 1$ ), grains are much smaller (average grain size of $\sim 13 \mu \mathrm{m}$ ) because they must undergo more rapid cooling. Apart from this zone, the microstructure remains globally homogeneous in the "useful" part of the cylinder as well as in the base, with an average grain size of $\sim 50 \mu \mathrm{m}$.

The grain size difference in between the zone $\mathrm{CH} 1$ and $\mathrm{CH} 3$ can be explained by the origin of the steel in the semisolid billet and the associated temperature difference since it is not homogeneous in the volume. The simulated temperatures of the $\mathrm{CH} 3$ zone are higher by 10 to $20^{\circ} \mathrm{C}$ and the photos of the part at the end of thixoforging (Fig. 14) show a clear temperature difference between the zone $\mathrm{CH} 1$ and $\mathrm{CH} 3$. It should also be noted that the volume of steel in the $\mathrm{CH} 3$ zone is twice as large. Under these conditions, the grains size of the microstructure of $\mathrm{CH} 1$ volume zone is completely solidify at end of forging. However, because of the higher temperature and a larger volume of steel, the microstructure grain size of the $\mathrm{CH} 3$ zone may have grown more than that of the $\mathrm{CH} 1$ zone until the end of the shaping and perhaps after.

Regarding the grain size of the zone CH1, ASTM 9, it is smaller than the raw material, ASTM 7. This indicates that there have been events during heating and / or shaping that have resulted in this local decrease in grain size. The explanation is not certain but it is possible that the steel of zone $\mathrm{CH} 1$ originates from a semisolid zone with a higher liquid fraction since the liquid fraction in the semisolid slug volume is not homogeneous, and that the fine grains are resulted from rapid solidification. As shown in the simulation, the highest temperature range, $\mathrm{CH} 4$, at $1475^{\circ} \mathrm{C}$, enters the tube fairly far, suggesting that the semisolid of the slug is first penetrated in the cylinder. Moreover, in this zone according to the simulations the shear stresses are low, more so than in the $\mathrm{CH} 2$ and $\mathrm{CH} 3$ zones and the grains are not equiaxed, which tends to say that they do not come from a recrystallization.

The microstructure of this thixoforged cylinder also differs substantially from that observed in parts forged through the conventional forging process. Grains of the thixoforged specimens exhibit a more random shape with rugged contours. The grain size is larger than that obtained through conventional forging (the forged grains are equiaxed, with an average grain size of $\sim 30 \mu \mathrm{m}$ ) because such rugged grains might adversely affect the magnetic properties; thus, a subsequent annealing step is recommended to tend to more equiaxed grains.

Fiberization is evident in the cylinder (Fig. 13), consistent with the material flow observed in Figure 13b. This fiberization is attributed to impurity segregation occurring during the various hot deformation steps (e.g. during rolling step of raw material). Notably, this fiberization tendency was already observed in the alloy before the thixoforging step as a result of rod shaping. However, no elongation of ferrite grains in the fiberization direction was observed.

\subsection{Observation of geometric and macrographic singularities}

Concerning the geometrical singularity, the semisolid steel moves more rapidly along the punch than along the outer die, which has the effect of creating a free surface at the end of the tube, which is not planar (Fig. 13b). A difference in flow exists for the two directions of forward or backward thixoextrusion. This difference is attributed at coupling of two effects. First effect is the difference in roughness energy heavily absorbed by the wall of the forging die and by the outer diameter of the tube, which is greater than that absorbed by the surface of the punch in cases of cold forging (Schrader et al., 2007). The second is the higher heat exchange between semisolid steel and die that between the semisolid and the punch. So during thixoforging the material consistence on outside is higher than for the inside diameter material and in this case the material flow is more difficult. This 
geometrical singularity can also observed with the simulations. According to this study, the difference in flow found between forward and backward extrusion processes is not very different. Second singularity, the fiberization in the $\mathrm{CH} 1$ and $\mathrm{CH} 2$ zones is almost not visible. The material of the $\mathrm{CH} 1$ and $\mathrm{CH} 2$ zones arises from an important flow of the hottest parts of the semisolid slug. This lack of fiberizing indicates certainly that the flow of steel into the tooling was done in a semisolid state and so the macrostructure most certainly comes from solidification and there is no trace of the primary steel from row material.

\section{Conclusion}

According to the DTA measurements, a precise and repeatable semisolid state of low-carbon SAE1006 steel is difficult to obtain because of the high melting start temperature and because of the small temperature range of the semisolid zone. But the experimental protocol in this study made it possible to obtain very repeatable heating of the slug and good parts even if the temperature in the slug volume is not uniform. In this context, the present paper reported (1) the heating process (2) the dimensional results and (3) the microstructure and flow behaviour during thixoextrusion tests of SAE1006 steel. Results show:

1. The method to define the time range of developed heating cycle to obtain the necessary semisolid state of SAE1006 steel compatible with the thixoforging processes.

2. The dimensional and geometrical tolerances obtained on the thixoforged part are very good and respond at the imposed conditions. The selected part geometry cannot currently be obtained, in one step, by conventional forging.

3. The flow of semisolid SAE1006 steel during thixoforging was good and did not cause defects (e.g., shrinkage, cavities, etc.). The observation of absence of fiberizing in certain zone of the part confirmed that it was certainly formed in the semisolid state.

In regard to the thixoforging of this steel, strong dimensional and structural part characteristics can be achieved through parametric adjustments to the process, tool temperatures, speeds and/or shaping energy levels. Based on the results of this study, we have validated the use of an additional steel grade, SAE1006, thus broadening the scope of steel thixoforging. Of course, investigations of the parameters of material driving in terms of thixoforgability are necessary to further model and apply this approach to other conditions. It should be noted that, in parallel, it is necessary to continue to investigate deeper the impact of the liquid fraction inhomogeneity in the heated slug, the oxide layer, thermal transfers on shaping, defects, microstructures, segregations, etc., to have better vision on the different phenomena of the thixoforging process. It is also necessary to study the tool wear associated with this type of shaping in order to verify the potential for transfer to industry. 


\section{Acknowledgements}

The authors would like to sincerely thank Grégory Lecomte of VALEO, Arnaud Quillery of the NEEL CNRS Laboratory, Florian Baratto, Jean-Baptiste Croué and Olivier Gyss of AMVALOR, Alexandre Fendler and Lionel Simon of the LCFC Laboratory for their technical contributions, and the PSPC Foundation for the financial support.

\section{References}

Aqida, S.N., Maurel, M., Brabazon, D., Naher, S., Rosso, M., 2009. Thermal stability of laser treated die material for semi-solid metal forming. Int. J. Mater. Form. 2, 761-764. doi:10.1007/s12289-009-0540-7

Becker, E., 2008. Investigations expérimentales et numériques pour l'identification des paramètres clefs du procédé de thixoforgeage de l'acier sur le produit mis en forme. Arts et Métiers ParisTech.

Becker, E., Bigot, R., Langlois, L., 2010. Thermal exchange effects on steel thixoforming processes. Int. J. Adv. ... 48, 913-924. doi:10.1007/s00170-009-2353-8

Behrens, B., Fischer, D., Haller, B., Rassili, A., Klemm, H., Walkin, B., Karlsson, M., Robelet, M., Cucatto, A., 2004. Introduction of a Full Automated Process for the Production of Automotive Steel Parts. 8th Int. Conf. Semi-Solid Process. Alloy. Compos. 77-88.

Bigot, R., Becker, E., Langlois, L., 2013. Some approaches on industrialization of steel thixoforging processes, in: Solid State Phenomena. Laboratoire Conception Fabrication Commande Arts et Métiers ParisTech, EA 4495, 4 rue Augustin Fresnel, 57078 Metz Cedex 03, France, pp. 521526.

Cézard, P., 2006. Impact des effets thermiques sur le comportement du matériau lors de la mise en forme des aciers à l'état semi-solide: analyses expérimentale et numérique. Arts et Métiers Metz.

Cézard, P., 2006. Impact des effets thermiques sur le comportement du matériau lors de la mise en forme des aciers à l'état semi-solide: analyses expérimentale et numérique. Arts et Métiers ENSAM Metz.

Cezard, P., Bigot, R., Becker, E., Mathieu, S., Pierret, J.C., Rassili, a., 2007a. Thixoforming of Steel: New Tools Conception to Analyse Thermal Exchanges and Strain Rate Effects. AIP Conf. Proc. 907, 1155-1160. doi:10.1063/1.2729670

Cezard, P., Bigot, R., Favier, V., Robelet, M., 2007b. Thixoforming of Steel : Experiments on Thermal effects. Adv. Methods Mater. Form. 117, 309-320. doi:10.1007/3-540-69845-0_20

Cézard, P., Sourmail, T., 2008. Thixoforming of steel: A state of the art from an industrial point of view, in: Solid State Phenomena. Trans Tech Publications Ltd, pp. 25-35.

Fischer, D., 2008. Entwicklung eines vollautomatisierten Produktionsprozesses für die Herstellung von Stahlbauteilen durch Thixoschmieden. IFUM Hannover.

Gu, G., Pesci, R., Langlois, L., Becker, E., Bigot, R., 2015. Microstructure investigation and flow behavior during thixoextrusion of M2 steel grade. J. Mater. Process. Technol. 216, 178-187. doi:10.1016/j.jmatprotec.2014.09.009

Gu, G.C., Pesci, R., Becker, E., Langlois, L., Bigot, R., Scheel, M., 2012. Quantification and localization of the liquid zone of partially remelted M2 tool steel using X-ray microtomography and scanning electron microscopy. Acta Mater. 60, 948-957. doi:10.1016/j.actamat.2011.10.039

Gu, G.C., Pesci, R., Langlois, L., Becker, E., Bigot, R., Guo, M.X., 2014. Microstructure observation and quantification of the liquid fraction of M2 steel grade in the semi-solid state, combining confocal laser scanning microscopy and X-ray microtomography. Acta Mater. 66, 118-131. doi:10.1016/j.actamat.2013.11.075

Hirt, G., Bleck, W., Bührig-Polaczek, A., Shimahara, H., Püttgen, W., Afrath, C., 2006. Semi solid casting and forging of steel, in: Solid State Phenomena. Trans Tech Publications Ltd, pp. 34 43. 
Hirt, G., Shimahara, H., Seidl, I., Kuthe, F., Abel, D., Schonbohm, A., 2005. Semi-Solid Forging of 100Cr6 and X21 OCrW12 Steel. CIRP Ann. - Manuf. Technol. 54, 257-260.

Khizhnyakova, L., Ewering, M., Hirt, G., Bobzin, K., Bagcivan, N., 2010. Metal flow and die wear in semi-solid forging of steel using coated dies. Trans. Nonferrous Met. Soc. China (English Ed. 20, s954-s960. doi:10.1016/S1003-6326(10)60613-9

Kopp, R., Kallweit, J., Möller, T., Seidl, I., 2002. Forming and joining of commercial steel grades in the semi-solid state. J. Mater. Process. Technol. 130-131, 562-568.

Lozares, J., Azpilgain, Z., Hurtado, I., Loizaga, I., 2014. Analysis of a Thixo-Lateral Forged Spindle from LTT C45, LTT C38 and LTT 100Cr6 Steel Grades. Solid State Phenom. 217218, 347-354. doi:10.4028/www.scientific.net/SSP.217-218.347

Lozares, J., Azpilgain, Z., Hurtado, I., Ortubay, R., Berrocal, S., 2012. Thixo Lateral Forging of a Commercial Automotive Spindle from LTT45 Steel Grade. Key Eng. Mater. 504-506, 357360. doi:10.4028/www.scientific.net/KEM.504-506.357

Mohammed, M.N., Omar, M.Z., Salleh, M.S., Alhawari, K.S., Kapranos, P., 2013. Semisolid metal processing techniques for nondendritic feedstock production. ScientificWorldJournal. 2013, 752175. doi:10.1155/2013/752175

Omar, M.Z., Alfan, A., Syarif, J., Atkinson, H. V., 2011. Microstructural investigations of XW-42 and M2 tool steels in semi-solid zones via direct partial remelting route. J. Mater. Sci. 46, 7696-7705. doi:10.1007/s10853-011-5749-4

Omar, M.Z., Atkinson, H.V., Kapranos, P., Jaharah, A.G., n.d. Mechanical Properties and Fracture Surfaces of Thixoformed HP9/4/30 Steel 1185-1190.

Püttgen, W., Bleck, W., 2004. DTA-measurements to determine the thixoformability of steels. Steel Res. Int. 75, 531-536.

Püttgen, W., Bleck, W., Hirt, G., Shimahara, H., 2007. Thixoforming of Steels - A Status Report. Adv. Eng. Mater. 9, 231-245. doi:10.1002/adem.200700006

Rassili, A., Adam, L., Fischer, D., Robelet, M., Demurger, J., Cucatto, A., Klemm, H., Walkin, B., Karlsson, M., Flüß, A., 2004. Improvement of materials and tools for thixoforming of steels, in: Proceedings of the 8th International Conference on Semi-Solid Processing of Alloys and Composites, S2P 2004. pp. 533-543.

Rassili, A., Atkinson, H.V., 2010. A review on steel thixoforming. Trans. Nonferrous Met. Soc. China 20, s1048-s1054. doi:10.1016/S1003-6326(10)60629-2

Rassili, A., Robelet, M., Fischer, D., 2006. Thixoforming of Carbon Steels: Inductive Heating and Process Control. Solid State Phenom. 116-117, 717-720. doi:10.4028/www.scientific.net/SSP.116-117.717

Robelet, M., 2004. EP1426460A1 C38LTT.

Schrader, T., Shirgaokar, M., Altan, T., 2007. A critical evaluation of the double cup extrusion test for selection of cold forging lubricants. J. Mater. Process. Technol. 189, 36-44. doi:10.1016/j.jmatprotec.2006.11.229

Winship, J.T., 1978. Fundamentals of Forging. Am. Mach. p 99-122.

Yi, M., Sugiyama, S., Yanagimoto, J., 2012. Effect of Recrystallization and Partial Melting Method on Microstructural Evolution of SKD61 Tool Steel in Semi-Solid State. Solid State Phenom. 192-193, 209-214. doi:10.4028/www.scientific.net/SSP.192-193.209 